\title{
ESTADO DA RALÉ: DA POBREZA À MISÉRIA NA OBRA DE JOÃO ANTÔNIO ${ }^{1}$
}

\section{Júlio Cezar Bastoni da Silva \\ Universidade Federal de São Carlos}

\section{Resumo}

O artigo aborda os últimos anos da produção do escritor João Antônio, em especial suas crônicas publicadas na imprensa, enfocando a posição de sua obra tardia na representação das questões que envolvem as mudanças sociais brasileiras das últimas décadas do século XX.

\section{Abstract}

The article covers the last years of João Antônio's literaray production, especially his chronicles published in the press, focusing on the positions of his later work on the representation of Brazilian social changes issues in the last years of XXth century.
Palavras-chave:

João Antônio; crônica; projeto literário; povo; violência; política
Keywords:

João Antônio; chronicle; literary project; folk; violence; politics

\footnotetext{
${ }^{1}$ Pesquisa financiada por meio de convênio FAPESP/CAPES.
} 
João Antônio, escritor e jornalista paulistano, pode ser considerado um herdeiro da antiga tradição intelectual brasileira ligada à reflexão e à projeção estética da formação nacional. A obra de João Antônio, cuja estreia data de 1963, com Malagueta, Perus e Bacanaço, revela intensa ligação com o caldo cultural presente na década de 1960, na qual a ideia de nacional-popular toma conta das artes brasileiras, uma pretendida comunhão espiritual do intelectual ou artista com a raiz cultural das classes subalternas, do povo brasileiro. Trata-se do interesse pelo que João Antônio chama, no ensaio-manifesto "Corpo-a-corpo com a vida" de "faixas de vida" populares, às quais o escritor deve se aproximar, de modo a dirimir as distâncias entre sua produção e a experiência popular. Sua ideia de povo, portanto, apresenta grande semelhança à das artes de mesma inspiração da década de 1960, momento de agitação política na produção cultural brasileira: são as classes subalternas, urbanas ou rurais, marginalizadas mas detentoras de uma autenticidade que garantiria sua posição como guardiã da brasilidade, da particularidade nacional. Essa particularidade serviria à formação de um país autônomo, moderno e democrático, uma "civilização tropical"’ quando da plena integração das classes subalternas na vida nacional, dirimindo a clivagem social brasileira. Como lembra João Luiz Lafetá, porém, a ideia de uma literatura capaz de expressar a "nação brasileira" e seu "povo" - isto é, nacional-popular -, "é tão velha quanto a própria literatura brasileira". ${ }^{4}$ Do romantismo à arte política da década de 1960, passando pelo modernismo, a integração entre produção artística e inspiração popular, via interesse do intelectual pelas classes subalternas, aparece como uma constante, forma de compreensão e participação da cultura nos destinos da nação.

Diferentemente da produção da década de 1960, porém, a obra de João Antônio não possuía a mesma ênfase politicamente engajada que marcara, por exemplo, as peças de um Oduvaldo Vianna Filho, a poesia de Ferreira Gullar ou mesmo o painel da revolução brasileira do romance de um Antonio Callado. A questão, na obra de João Antônio, parece ser, ao longo de toda a sua trajetória, desenvolver um projeto literário que procure representar a experiência popular, em especial a da população urbana socialmente marginalizada ou do trabalhador pobre, sem soluções políticas presentes no entrecho, mas apenas latentes, vazadas em forma de denúncia. Em "Corpo-a-corpo com a vida", assim, o autor afirma que o que “(...) carecemos, em essência, é o levantamento de realidades brasileiras, vistas de dentro para fora. Necessidade de que assumamos o compromisso com o fato de escrever sem nos distanciarmos do povo e da terra". ${ }^{5}$ João Antônio, deste modo, se coloca na esteira de grande parte da tradição literária brasileira, no seu caso, em especial, dos intelectuais modernistas, sem desprezar a inspiração sempre por ele lembrada de Lima Barreto, Euclides da Cunha ou de Graciliano Ramos, autores que, segundo ele, permaneceram justamente por firmarem “(...) um compromisso sério com o fato social, com o povo e com a terra”. ${ }^{6}$ Assim, Malagueta, Perus e Bacanaço, especialmente, e, de certo modo, toda a obra joãoantoniana possui relação com o chamado "período populista" nas artes, embora com ele não compartilhasse o compromisso de uma militância, em última análise, vinculada às diretrizes de organizações políticas.

Em especial a partir da década de 1970, a produção ficcional e jornalística de João Antônio passa a se integrar de maneira progressiva, ocasionando certa hibridez de gêneros que manterá até o fim de sua trajetória. A caracterização pacífica, quase idílica, sobretudo empática, da marginalidade urbana e

\footnotetext{
${ }^{2}$ ANTÔNIO, João. “Corpo-a-corpo com a vida”. In: Malhação do Judas Carioca. Rio de Janeiro: Civilização Brasileira, 1975 , p. 143.

${ }^{3}$ RIDENTI, Marcelo. Brasilidade revolucionária. São Paulo: Editora UNESP, 2010, p. 9-10.

${ }^{4}$ LAFETÁ, João Luiz. "Traduzir-se: ensaio sobre a poesia de Ferreira Gullar". In: A dimensão da noite e outros ensaios. São Paulo: Duas Cidades; Editora 34, 2004, p. 121.

${ }^{5}$ ANTÔNIO, op. cit., p. 143.

${ }^{6}$ Ibidem, p. 144.

${ }^{7}$ AGUIAR, Flávio. "Evocação de João Antônio ou do purgatório ao inferno". In: CHIAPPINI, Lígia; DIMAS, Antonio; ZILLY, Berthold (Orgs.). Brasil, país do passado? São Paulo: Boitempo; EdUSP, 2000, p. 150.
} 
do trabalhador miúdo, que marca Malagueta..., passa progressivamente a enfatizar as contradições de um país que saíra do "milagre" econômico da última ditadura brasileira, adensando a representação das mazelas urbanas, como o inchaço populacional, a criminalidade, a mendicância, a luta pela sobrevivência nas metrópoles brasileiras, em especial o Rio de Janeiro. No entanto, é importante frisar que João Antônio nunca chegaria à representação da criminalidade e da violência urbanas típica de um Rubem Fonseca, por exemplo. Ambos, embora reunidos pela crítica coetânea como representativos de uma mesma tendência - chamada "realismo feroz" ou "brutalismo" - são fundamentalmente diversos na forma de abordar o fenômeno urbano. Enquanto o problema, para Fonseca, é a violência disseminada, interior e mesmo natural, cuja justificação parece escapar a qualquer racionalização que vise determinar suas causas, João Antônio compreende a violência dentro de um universo de desigualdade ou iniquidade social, o que se confirma não apenas na ambientação ou situação de seus personagens no meio precário brasileiro, mas na própria estilização da fala popular, uma estratégia narrativa que sugere compreensão e identidade com o ente popular retratado. Novamente, é importante lembrar que João Antônio se filia à tradição literária brasileira comprometida com a questão popular, enquanto Rubem Fonseca já projeta, desde suas primeiras obras, a linguagem da violência que predominará nas letras brasileiras nas últimas décadas do século passado e no início deste. As mudanças sociais brasileiras, o recrudescimento da violência urbana, a banalização das atrocidades veiculadas pelos diversos meios de comunicação, enfim, o futuro "(...) afinou-se melhor ao projeto literário de Rubem Fonseca", em detrimento da preocupação social que João Antônio exprimia em seus textos. ${ }^{10}$ As mudanças ocorridas na sociedade brasileira não deixaram de ser trabalhadas por João Antônio, mas a herança intelectual que toma como sua, bem como sua devoção ao povo brasileiro, com o horizonte em um projeto nacional, determina em sua literatura um sentimento de perda, nostalgia e lamentação pela situação brasileira, em especial no período pós-redemocratização. ${ }^{11}$

A obra de João Antônio, publicada entre 1963 e 1996, deste modo, apresenta um painel das mudanças ocorridas no país, por meio da forma em que apresenta as questões ligadas às classes populares brasileiras e às transformações urbanas, foco de sua produção. A última produção de João Antônio, entre meados da década de 1980 até 1996, prioriza o gênero da crônica. Nela, João Antônio dá vazão à sua avaliação sobre a sociedade brasileira, de modo ainda mais pessoal que nos contos de sua última lavra. De fato, depois de Abraçado ao meu rancor (1986), obra na qual já era plenamente verificável uma crise na produção do autor, desponta um impasse pessoal ante o estado da sociedade brasileira modificada, contra a qual se volta no que Lafetá chama de "estética do rancor": aumentara a "brutalidade da exploração capitalista no Brasil", ${ }^{12}$ gerando reativamente o inconformismo, a indignação e o ressentimento, em especial nos intelectuais de classe média empenhados na construção da nacionalidade. Livro publicado logo ao final da ditadura militar, Abraçado ao meu rancor ainda exprimia o mesmo ar irrespirável, bem como já pressupõe a continuidade de certos problemas relacionados à desigualdade brasileira e à distância entre Estado e sociedade, que não seria redimida no novo período.

Ainda na década de 1990, João Antônio carregava sua herança romântica a tiracolo. Povo brasileiro, cultura nacional e valorização do país jamais deixariam de aparecer em sua obra, mesmo a custa de que suas declarações ou textos parecessem deslocados frente ao projeto nacional naquela década já em

\footnotetext{
${ }^{8}$ CANDIDO, Antonio. "A nova narrativa”. In: A educação pela noite. 5. ed. Rio de Janeiro: Ouro sobre Azul, 2006, p. 255. ${ }^{9}$ BOSI, Alfredo. "Situação e formas do conto brasileiro contemporâneo". In: O conto brasileiro contemporâneo. 8. ed. São Paulo: Cultrix, 1978. p. 18.

${ }^{10}$ LACERDA, Rodrigo. João Antônio: uma biografia literária. Tese (Doutorado em Teoria Literária e Literatura Comparada)-FFLCH, USP, São Paulo, 2006. 2 v. p. 440.

${ }^{11}$ Ibidem, p. 443. "A obra de João Antônio documenta essas transformações, em vários níveis, mas seu vetor emocional vai sempre na direção oposta".

${ }^{12}$ LAFETÁ, João Luiz. "João Antônio e sua estética do rancor". In: A dimensão da noite e outros ensaios. São Paulo: Duas Cidades; Editora 34, 2004, p. 517.
} 
decadência. Depois de vinte anos de ditadura militar, de modernização conservadora e de uma integração radical ao capitalismo internacional, com todos os efeitos decorrentes de uma globalização contraditória, que solapa a perspectiva de uma emancipação nacional no antigo sentido dado ao termo, parece que mesmo os discursos potencialmente contra-hegemônicos não podem deixar de lado sua filiação a uma perspectiva universalizante, na qual os novos paradigmas, ligados a signos e práticas compartilhados internacionalmente, parecem, numa primeira mirada, derivar seu impulso do próprio fim dos projetos particularistas, dos quais o nacional é parte integrante. No entanto, em um país no qual a integração moderna não se alcançou, tendo como parâmetro os países desenvolvidos - também não isentos de cisões sociais, é bom lembrar -, a questão nacional retorna sempre como espectro, com uma nova versão não mais garantida pelo Estado desenvolvimentista, mas em interação conflituosa com o capitalismo global. Se "o mercado não é para todos", ${ }^{13}$ as demandas postas no passado retornam na situação agônica de uma provável aporia, na qual a afirmação nacional mira num alvo talvez inexistente. Nesse panorama, é perceptível, a partir da década de 1980, não exatamente uma decadência qualitativa da obra de João Antônio, mas uma dissonância frente às mudanças que então ocorrem na sociedade e cultura brasileiras. José Paulo Paes, assim, coloca João Antônio na linhagem rancorosa de um Gregório de Matos, enfatizando que a falência não é apenas do país, mas do próprio projeto literário de um autor que projetara se irmanar ao povo em suas obras e jornalismo. Haveria, então, em Abraçado ao meu rancor, uma "diatribe" contra os escribas, "sabujos" e "lacaios do Poder", "mas também, e sobretudo, um mea culpa". ${ }^{14}$ Há uma espécie de identificação entre a crise nacional e a avaliação do próprio ofício, antes entendido pelo autor na chave do empenho em nome do povo brasileiro, em especial dos desclassificados sociais, por quem a literatura joãoantoniana demonstra algo maior que a simpatia. Sobre "Abraçado ao meu rancor", conto do livro homônimo, Bosi nota que a saudade "muda (...) em sentimento de protesto", uma negação da São Paulo no tempo da "civilização de massas", ${ }^{15}$ plena de referências ao imperialismo ianque e ao inferno do mercado globalizado. São tempos nos quais o nacional, via lamentação da perda da autenticidade popular brasileira passa a entrar pela linguagem da nostalgia, mudando a forma em que o engajamento de sua obra pregressa era vazado. A manutenção da mesma perspectiva, nacionalista ou patriótica - sempre romântica -, com ênfase na valorização do caráter popular, torna-se, pela própria realidade de negação e massificação desta população na nova civilização urbana brasileira, para João Antônio, um fardo pesado a carregar, um elemento mal resolvido em seu projeto literário. Se adequado à agitação intelectual da década de 1970 , no protesto contra os efeitos avessos do "milagre" econômico da ditadura, a partir da década de 1980 ele passa a soar deslocado, com o agravante de os problemas sociais em que mirava permanecerem os mesmos, talvez piorados, certamente diferentes.

Nas crônicas que produz, da década de 1970 à de 1990, sobre o Rio de Janeiro e, em especial, Copacabana, essa situação pode ser bem compreendida. Ô Copacabana!, livro publicado em 1978, reúne diversos textos já publicados anteriormente por João Antônio, em especial em suas crônicas na imprensa alternativa, como em Movimento, Versus e O Pasquim, entre 1974 e 1976. Este livro é uma visada de conjunto sobre a situação urbana no Rio de Janeiro, uma espécie de exposição do avesso do famoso bairro carioca. A especulação imobiliária, a miséria, as mudanças nos ambientes boêmios, são os elementos lembrados por João Antônio nestes textos, enfeixados em uma extensa crônica. Deve-se notar, assim, que o teor crítico sempre foi característica presente na obra de João Antônio; lembremos

\footnotetext{
${ }^{13}$ SCHWARZ, Roberto. "Fim de século”. In: Sequências brasileiras. São Paulo: Companhia das Letras, 1999, p. 161.

${ }^{14}$ PAES, José Paulo. "Ilustração e defesa do rancor". In: A aventura literária: ensaios sobre ficção e ficções. São Paulo: Companhia das Letras, 2001, p. 111.

${ }^{15}$ BOSI, Alfredo. "Um boêmio entre duas cidades". In: ANTÔNIO, João. Abraçado ao meu rancor. Rio de Janeiro: Guanabara, 1986, p. 7-8.
} 
que sua obra é perfeitamente adequada ao clima intelectual da década de 1970, em especial o de oposição à modernização sem democratização social ocorrida na ditadura militar. $\mathrm{O}$ espaço urbano e seus personagens entram, pois, como dados simbólicos de um desenvolvimento desigual, lesivo às camadas mais pobres e aparente mesmo num dos cartões-postais da cidade do Rio, aqui elevada a uma espécie de sinédoque nacional, microcosmo das mudanças brasileiras. No entanto, percebe-se, latente, o apreço pelo espaço, embora criticado; daí, a frase que abre e sintetiza bem o espírito do texto: "eu te bato porque te amo" ${ }^{16}$ A tônica, portanto, desta grande crônica, está sempre na exposição do avesso da face conhecida e turística de Copacabana, como símbolo de um progresso ao qual apenas a face aproveitável ao poder político e econômico é dada a público: “Copacabana mito, a máscara jamais caiu de todo": "[há] uma Copa não folclorizada e que sai do feixe de afobações, especulações e gulas e acaba como imagem descarnada de nossas aflições pelo desenvolvimento e progresso. Ou daquilo que chamamos assim. Teria sido certo crescer tanto em pouco mais de setenta anos?"18 As "aflições pelo desenvolvimento e progresso" são, na voz do cronista, as causas de uma situação de iniquidade, da qual a parte prejudicada é a que pretende expor. Trata-se, sobretudo se lembrado o momento pós-'milagre' econômico, de revelar os desvãos da sociedade brasileira, por meio de um programa estético e político. Nessa representação do bairro, participam a crítica, o sarcasmo e a ironia, não raramente descambando para um cinismo bem calculado, quando questiona a imagem festiva do ambiente, frente a sua situação real precária, pronta a se mostrar diuturnamente mesmo ao mais desavisado: “[não] estamos nem aí. Pedimos passagem aos mendigos e vamos tocando. Que temos a praia e o botequim. ${ }^{19}$

O olhar do narrador-cronista, assim, volta-se para as contradições urbanas legadas pelo dito progresso, talvez insuspeitas ou ignoradas pelo olhar da apologia. Já na década de 1970, portanto, a crítica de João Antônio é patente, embora ainda não totalmente envolta nas malhas de uma desesperança pelo futuro nacional: "[apesar] da patifaria e da devastação, da exploração e do aviltamento, do terror e das denúncias vazias, do caos ganhando da gente, da pouca-vergonha, ainda não nos mataram o amor". ${ }^{20} \mathrm{Na}$ década de 1990, quando retoma o tema do bairro e do Rio de Janeiro em seus textos, a relação afetiva com o espaço, que aparece contraditoriamente na década de 1970, aparece travestida pela nostalgia e pelo desengano, o que faz com que o sentimento misto de amor e ódio da década de 1970 se transmute em lamento. No entanto, permanece a mesma ideia da valorização do povo brasileiro e do desejo de uma mudança social no país, agora ainda mais encobertos após a redemocratização, que dera em nada na resolução destes problemas. Como lembra Rodrigo Lacerda, trata-se de um período no qual "[esvaíra-se] a aliança entre a militância e a intelectualidade de esquerda, provenientes da classe média, e o chamado 'povo', esmagada primeiro pelos militares, e depois pelas transformações da conjuntura histórico-ideológica (...)"; ;1 a permanência de João Antônio no mesmo círculo de valores intelectuais dissemina nos seus textos a sensação de estar fora do lugar e do tempo, de lamentar um passado que nunca fora idílico, mas prenhe de utopias. Na crônica de 1992 "Estado da ralé”, o Rio aparece novamente de maneira metonímica em relação ao país, cujos males, portanto, não apenas compartilha, mas representa e projeta:

\footnotetext{
${ }^{16}$ ANTÔNIO, João. Ô Copacabana! Rio de Janeiro: Civilização Brasileira, 1978, p. 11.

${ }^{17}$ Ibidem, p. 44.

${ }^{18}$ Ibidem, p. 65.

${ }^{19}$ Ibidem, p. 26-27.

${ }^{20}$ Ibidem, p. 67.

${ }^{21}$ LACERDA, op. cit., p. 440.
} 
Se o Rio vai mal, é o Brasil que não vai bem. Além da sua beleza de cidade-mulher, epidérmica, disparadamente uma mulher bonita que não precisa de jóias, disse um de seus cronistas, a cidade de São Sebastião é síntese. Funciona, se preferirem, como um sovaco do corpo brasileiro. O termômetro debaixo do sovaco acusa febre. É o Brasil que está com febre; não isoladamente o Rio de Janeiro. ${ }^{22}$

"Estado da ralé" é uma espécie de balanço, pela visão do escritor, da situação brasileira, a partir da mirada sobre o Rio de Janeiro. Dos males do momento, fica principalmente patente a decepção com a recente redemocratização, que não cumpriu as esperanças gestadas quando da abertura, destacando os dois males que, a seu ver, caracterizariam o Rio de Janeiro e, por extensão, o país: o "pauperismo geral" e a "violência".

Fica impossível (...) falar-se em direitos humanos depois que nos cassaram a cidadania, direito primeiro, passando sobre uma constituição nova, recente, ainda fresca, a mais cara, demorada e sofrida da história da chamada república. Tudo em nome de um Brasil novo com um estilo a que xingam de modernizante. ${ }^{23}$

O período de crise entre a redemocratização e os primeiros anos da década de 1990 - últimos anos da produção e da própria vida do escritor, aliás - aparece como um tempo de mudanças substantivas, todas aparentemente negativas, em especial porque contrariaram as esperanças anteriores no país. Trata-se de um sentimento generalizado entre a intelectualidade brasileira de que havia uma democracia traída, no sentido de que houve a continuidade de antigos vícios e, em especial, a manutenção da desigualdade que explode então em uma sociedade plenamente orientada para o capitalismo mundializado. Para João Antônio, a experiência social, que transforma em crônica, jornalismo e literatura, no entanto, é o que determina a visão afetiva sobre os fenômenos brasileiros do momento. Assim, a percepção das mudanças não é fruto da análise fria das estatísticas ou da política, mas da tentativa de compreender o estado geral do país, partindo da ligação direta que sempre intentara realizar com as "faixas de vida" nacionais, em especial as classes subalternas. Assim, João Antônio traduz em estética uma mudança social perceptível, na qual as utopias e o projeto de nação são postos de lado, o que lhe causa o tom de desencanto. Assim, na crônica "Mendigos e mafueiros", afirma o autor:

Agora, tempos piorados. $\mathrm{E}$ as nossas cidades nunca souberam esconder o miserê. $\mathrm{O}$ que tinha, o que tem de miséria, sempre gritou.

Hoje, a miséria desceu o morro e escorreu de algum canto rural e se plantou no asfalto. A rua virou lugar de tumulto e isto não é nenhuma novidade. Os tempos estão brabos e, sem pedir licença, a miséria substituiu a pobreza em plena rua. Feia, suja, ela dá também para atrevida, perturbadora, inconveniente. (...) Há tropelias, correrias, gritarias e ninguém está brincando de pega-ladrão. ${ }^{24}$

Os "tempos piorados" notados pelo cronista são sintetizados pela expressão de que "a miséria substituiu a pobreza". Esta expressão condensa a passagem de uma exclusão social nas cidades ainda incipiente à explosão da população urbana entre a década de 1960 e 1970 . A pobreza do antigo ambiente quase rural passa agora a se misturar à vida do asfalto, um compartilhamento de espaço físico que, no entanto, não esconde a cisão social de fundo, baseada na desigualdade já histórica. A questão, porém, não é apenas a da existência de ambientes precários e da existência da pobreza, mas de um tipo de pobreza que não mais se enquadra na sociabilidade antiga, de caráter familiar e rural - à qual se volta de maneira nostálgica, evocando, em seus textos, lembranças de infância. Assim, em "Morro da Geada", texto memorialístico que abre o livro Zicartola e que tudo mais vá pro inferno! (1991), afirma o narrador-cronista:

\footnotetext{
${ }^{22}$ ANTÔNIO, João. "Estado da ralé". Rio Capital, Rio de Janeiro, n. 1, 11/1992, p. 7.

${ }^{23}$ Ibidem.

${ }^{24}$ ANTÔNIO, João. "Mendigos e mafueiros". Rio Artes, Rio de Janeiro, n. 19, 1995, p. 32.
} 
No morro éramos rurais. (...)

Nenhum de nós sabia dizer a palavra solidariedade. Mas a casa de outro tio, o nosso tio Otacílio, criavam-se até filhos dos outros, e estou certo que o nosso coração era simples, espichado e melhor. Não desandávamos a reclamar da vida, não nos hostilizávamos feito possessos, tocávamos a pé pra baixo e pra cima e quando um se encontrava com o outro, a gente não dizia: 'oi!'. A gente se salvava, largo e profundo: - Ô, batuta! ${ }^{25}$

A vivência que João Antônio identifica como autêntica é buscada num passado idílico, no qual, mesmo pobre, havia, segundo o cronista, a possibilidade de um viver ainda não contaminado pela vida na urbe moderna. Uma forma de combinação, portanto, da vida rural e urbana, em uma cidade que ainda não formara, de todo, a vivência na anonímia e na competição brutais.

A situação narrada na pequena crônica "Sem barulho", certamente um dos últimos textos de teor ficcional escritos por João Antônio, dá conta do novo clima da miséria brasileira. $\mathrm{O}$ assunto é bastante simples, e já trabalhado por João Antônio em outras ocasiões: trata-se da morte de um homem miserável, ocorrida, neste caso, na rodoviária do Rio de Janeiro. Sua morte não apenas não é notada, como se trataria de um incômodo ante os olhos bestializados das pessoas, para as quais a vida ou a morte de um pobre são indiferentes.

Cedo. Veio trêmulo, troncho, o saco de farinha imundo e quase vazio às costas. Arriou na poltrona e sofreu quieto, a cabeça bandeou e pendeu um tanto para a esquerda e endureceu. De todo.

Ali apagou sem barulho. Tempo correu, alguém se encabulou com aquele corpo imóvel e continuado. Foi tocado. E deram com o morto. Descobriram-se coisas no saco imundo. Um nome na carteira profissional. Inútil, não tinha trabalho ou patrão. Tinha morrido à míngua, só feito Job. Sua sujeira e sua solidão eram de causar nojo. Veio alguém com um saco de lixo, plástico preto. Um outro arranjou, cobriu o corpo da cintura para cima. Nem foi preciso que descruzassem os pés pretos dentro da sandália fuleira. Assim, o morto de fome, ensacado da cintura para cima, já não incomodava. Os outros puderam, em paz, cruzar as pernas, ler, conversar, ir e vir, enquanto esperavam o ônibus. Ele já não perturbava sequer a visão e a pressa da rodoviária, segunda grande do país.

Um Raimundo, descobriu a polícia. Com certeza, nada ouviu ou soube ao redor da palavra solidariedade. Sujo, só alterava um pouco; depois, morreu de fome sem barulho. Também não fez barulho depois de morto - não teve quem lhe reclamasse o corpo. Raimundo, solteiro ou casado, morreu como nem os cachorros morrem na cidade. (...)

A cidade tem litoral rico e terra tão fecunda forneceria três colheitas todo ano, milho e feijão. A firme Bolsa de Valores do país, a poderosa emissora de televisão, o segundo produtor industrial do Brasil, o Carnaval, maior festa popular do mundo, tem raio laser, computadores magníficos, infalíveis, uma ponte tão bonita e grande atravessa a baía. A cidade com alguns milhões de pessoas, chamada de muito heroica e gentil. ${ }^{26}$

A crônica relata a situação de anonímia e indiferença que reside na população da grande metrópole, brutalizada por um dia-a-dia e uma forma de vida que proscrevem a solidariedade e o reconhecimento do próximo enquanto indivíduo. $\mathrm{O}$ texto, narrado a partir de um distanciamento enviesado, parece refletir o tom de fato corriqueiro e sem consequências, para o qual a vida de um homem vale menos que a de um animal morto. O que choca, portanto, não está na narração, mas no fato narrado que, a partir do distanciamento em que é expresso, em consonância à indiferença dos demais personagens quanto à situação, traz ao leitor a situação brutalizada que é característica do homem na metrópole. Tampouco o morto chama a atenção:

\footnotetext{
${ }^{25}$ ANTÔNIO, João. Zicartola e que tudo mais vá pro inferno! 2. ed. São Paulo: Scipione, 2007, p. 20-22.

${ }^{26}$ ANTÔNIO, João. "Sem barulho". Jornal do Brasil, Rio de Janeiro, 12/9/1993, p. 7.
} 
morre sem barulho, sem despertar interesse de quem quer que fosse. A ironia final é bastante típica da obra de João Antônio, de temperamento afeito aos contrastes, em especial os que colocam lado a lado a riqueza e a miséria, ambas sem comunicação possível. O Rio de Janeiro, opulento, fértil e possuidor de riqueza cultural popular, é o mesmo ambiente no qual a miséria não exatamente convive com a relativa fartura, mas a ela é invisível. É importante notar que a situação remete ao conto "Bruaca", de Dedo-duro, que possui assunto semelhante, ao narrar a morte solitária do mendigo cambaio que dá nome à narrativa. Neste, porém, a morte, sentado em uma cadeira, com "as pernas cruzadas, os braços estendidos", "Ihe [dá] a panca de rei”. ${ }^{27}$ Nada mais distante do Raimundo da crônica: não há mais lugar para entronizar a miséria nos novos tempos, ainda que ironicamente. A “miséria que substitui a pobreza”, portanto, não é para João Antônio apenas a degradação material das condições de vida de certas camadas da população brasileira, mas a perda de certa vivência tradicional, aliás identificada com a sociabilidade autêntica nacional, que encontrava guarida nas camadas populares, no povo brasileiro. Nesse sentido, pode-se perceber em João Antônio a manutenção da mesma posição exercida durante toda a sua obra no tocante ao empenho por um projeto nacional de base popular, fato que, depois do combate mais encarniçado da década de 1970, passa a adotar, em fins da de 1980 e início dos anos 1990, tons nostálgicos e lamentosos pela perda da própria identidade, na qual projetava a utopia pregressa. O país mudou, e os sonhos foram postos em suspenso.

A nova face da miséria brasileira é, pois, para João Antônio, o caminho de uma desestabilização da identidade nacional, ainda incompleta, mas então em suspensão. A miséria, assim, estoura em competição, brutalidade urbana, trânsito e trabalho precário, uma piora de um quadro antigo de desigualdade, de novos e indesejados efeitos. A violência urbana, um dos temas favoritos de João Antônio, ganha novas tintas, num quadro que representa uma absorção pelo próprio crime da lógica do capitalismo periférico. A criminalidade dos primeiros textos, expressa por meio da representação da malandragem urbana, dá lugar, na obra de João Antônio, de modo progressivo, à criminalidade de novo tipo, a qual, a rigor, não apresentará em sua ficção. Embora possam ser notados uma maior densidade e mesmo rigor ao trabalhar os marginais urbanos, partindo do cotejo entre a estreia em Malagueta, Perus e Bacanaço até Abraçado ao meu rancor, passando por Leão-de-chácara e Dedo-duro, João Antônio não abandona de todo o interesse empático por essa figura do submundo das grandes cidades, fato que impede a avaliação deste novo tipo de criminalidade, afeito mais ao cálculo empresarial que à mera sobrevivência, não obstante também produto da mesma situação de pobreza material. Embora tenha reconhecido, já na década de 1970, que a ideia de malandro esteja ligada estreitamente a uma mistificação da vivência das classes populares brasileiras, não é possível dizer que João Antônio tenha, ao longo de sua trajetória, se livrado de certa idealização do povo ao qual dedica sua produção. Chega a afirmar, em meados daquela década, que

(...) não existe malandro. Embora eu tenha usado isso em 'Malagueta' e em 'Leãode-chácara' eu use menos, daqui pra frente vou usar cada vez menos. Realmente, não existe o malandro, existe é o merduncho, entende, que é um pingente urbano, um sobrevivente em péssimas condições. ${ }^{28}$

Trata-se, nesta entrevista de 1975, de um período no qual seu projeto literário dá uma guinada em favor da integração entre jornalismo e literatura, intensificando a proposta de realismo já presente em suas produções anteriores, em nome de um empenho para a representação dos problemas brasileiros na forma de protesto - questões levantadas no ensaio-manifesto "Corpo-a-corpo com a vida". Mesmo assim, haverá manutenção de determinadas posições pelo autor, como a valorização do povo brasileiro e sua

\footnotetext{
${ }^{27}$ ANTÔNIO, João. "Bruaca”. In: Dedo-Duro. 2. ed. Rio de Janeiro: Record, 1982, p. 180.

${ }^{28}$ O (SUB) MUNDO DE JOÃO ANTÔNIO. Crítica, Rio de Janeiro, n. 58, 15-21/9/1975, p. 17.
} 
filiação a um projeto nacional vazado pela literatura e pela cultura, o que, frente à debacle dos anos 1980 em diante, determina, em certo sentido, o seu progressivo afastamento do meio literário e ao esgotamento de sua veia ficcional. O escritor, depois de Abraçado ao meu rancor, se concentrará na crônica e na retomada dos perfis de personagens brasileiras, os quais sempre produziu em sua carreira periodística, desde a década de 1960. Trata-se de uma perceptível inadequação frente à nova realidade do país, o que o motiva a procurar novas formas de intervenção e de continuidade de sua produção. A ficção, o conto de João Antônio, parece não dar mais conta da realidade brasileira: seus personagens mudaram de figura e o espaço da cidade, agora inóspito e intolerável, torna-se avesso ao seu feitio.

João Antônio, em algumas crônicas da década de 1990, apresenta o novo tipo de crime como um dos elementos-chave da degradação urbana no final do século. Em "Rio: a arrepiante república da violência", de 1994, o autor liga a nova criminalidade à situação social do Brasil como um todo, do qual a cidade do Rio de Janeiro seria apenas um microcosmo, ponto de confluência e de maior exposição desta mudança na sociedade:

A violência está solta nas ruas, nos sinais de trânsito, ao pé dos morros e lá em cima mais ainda. A violência está dentro das conduções coletivas a partir do modo como se dirige uma condução coletiva no Rio de Janeiro. A violência começa no chão, onde, em pleno Centro da cidade, o calçamento de pedrinhas portuguesas vai esburacado por completo. Com ou sem inflação (visível) de dois dígitos, a luta brava da cidade segue com violência.

A violência pula para as primeiras páginas dos jornais, grita nas revistas, se expõe no quadrilátero iluminado das televisões e chega às capas dos livros. A violência não é do Rio: é do país. Brasília, Recife, Porto Alegre, Salvador, São Paulo... a violência se repete. (...)

Polícia corrupta e ladrões ou traficantes se confundem numa espécie de exposição pública de um novo 'poder': a violência. Todos ou quase todos os nossos conhecidos, amigos e parentes já foram assaltados ou nós mesmos o fomos. E nos morros a situação piora, há barricadas para se entrar. Entrar ou não, dependendo das ordens do chefe do tráfico de drogas do morro. Um poder paralelo estabelece os regulamentos: é preciso obedecê-lo, pois, sem o seu aval, não se sobe o morro. E, menos ainda, se desce. ${ }^{29}$

A nova forma de violência na sociedade brasileira, para João Antônio, estaria ligada a uma situação mais fundamental, que é a brutalização dos costumes como um todo. Trata-se, portanto, não apenas de novas formas de crime, mas elas configuram parte de um mesmo fenômeno de um país no qual a "miséria substituiu a pobreza": a nova criminalidade é tão filha dos novos tempos quanto a negação dos direitos de cidadania, a pressão econômica, o desrespeito com o espaço público, etc. No caso da criminalidade, porém, outro fator chama a atenção do cronista, que é a particularidade das facções criminais, grupos armados que substituem o Estado e fazem justiça e negócios a seu próprio alvitre. Na mesma crônica, João Antônio fala sobre o Comando Vermelho, facção criminosa carioca, cujo despontar se liga ao período da última ditadura e, no presente, faz “(...) parelha com a impunidade, [ao] inchaço da superpopulação e (...) na barriga de uma crise econômica”.30 Estamos distantes, como se vê, do pequeno marginal urbano de um conto como "Frio", do livro de estreia de João Antônio; o tráfico, no fim do século, possui outra dinâmica, a qual João Antônio não pôde expressar em ficção, deixando para a forma mais aberta da crônica sua mirada sobre este dado da sociedade brasileira. Essa nova dimensão da obra de João Antônio, porém, expõe os mesmos parâmetros pelos quais entende a sociedade brasileira e sua cultura, isto é, as concepções que possui sobre o seu tão valorizado povo. A angústia com a situação precária das classes

\footnotetext{
${ }^{29}$ ANTÔNIO, João. "Rio: a arrepiante república da violência". Tribuna da Imprensa, Rio de Janeiro, 19/9/ 1994a. Tribuna BIS, s. p.

${ }^{30}$ Ibidem.
} 
subalternas volta também, em fins de sua obra, à crítica ao poder político, mantendo, de certo modo, a linha de seus escritos da década de 1970. O que importa e é interessante em partes pouco conhecidas de sua trajetória, como o é a sua produção da década de 1990, é o caráter visceral de um acompanhamento da realidade brasileira que veio exercendo em múltiplas formas desde a década de 1970, em especial. A ficção parece ter secado sua fonte, aqui, afora breves lampejos, o que torna o caso ainda mais digno de ser entendido, bem como de ser compreendido como uma tragédia em seu projeto literário - tragédia que é, de qualquer modo, do próprio país ao qual se devotou.

Uma de suas crônicas da década de 1990 é uma mistura de agonia e utopia na construção de um país que ainda não encontrara seu termo, uma sociedade moderna e democrática, mais igualitária. Trata-se de "Em janeiro sonhamos", publicada no Jornal do Brasil. Nela, resposta a uma pergunta proposta pelo diário diante da primeira eleição de Fernando Henrique Cardoso, segundo presidente eleito pelo voto popular desde a redemocratização, João Antônio traça uma espécie de irônica utopia sobre o acontecimento, destacando as possibilidades sempre perdidas de redenção social do país, que certamente sabia não estarem sendo gestadas pelo futuro governo a assumir em janeiro do ano seguinte. Trata-se de um texto de ilusões perdidas antes mesmo do acontecimento futuro, dada a perene sensação de déjà $v u$ no tocante à insolubilidade por parte do Estado dos problemas sociais brasileiros.

Vamos dizer. No país das seis letras diferentes surgirá...

Já que estamos no terreno do imponderável, é possível que se levante uma bandeira alta e de abrangência nacional, tendo a inscrição: NENHUMA MISÉRIA SERÁ BELA. Varreremos do mapa, num golpe, todo o Absolutismo do Estado. A partir de primeiro de janeiro de 1995, com um emendão só, o governo há de ser um instrumento da sociedade ou, melhormente, um organismo que resolverá os problemas. E não, como até agora, um criador de problemas e de nós dramáticos. Para além de não equacionar as questões sociais, sequer resolve as dele.

Nesse emendão único resolveremos, logo no primeiro mês, a reforma agrária. O que não fizemos em cem anos de república, faremos num mês. As cidades se desincharão, multidões tornarão ao campo e a Favela da Rocinha, exemplo maior, ficará tão desabrigada a ponto de motivar o reflorestamento, de toda a área e recompor aquela faixa da Mata Atlântica, hoje careca e espetada de barracos e de alguma alvenaria. (...) Esse, só o começo. ${ }^{31}$

Trata-se de uma utopia pelo avesso, denunciada pelo uso de uma amarga ironia, durante todo o texto. A solução de todos os problemas nacionais pela volta da democracia não é mais algo factível depois de quase dez anos de permanência de antigos vícios e de velhos problemas do país. A eleição de um novo presidente, que motiva a renovação das esperanças, é pensada amargamente, com o texto se colocando de antemão como sabedor do novo fracasso a vir. Os exageros, assim, na solução de todos os problemas do país por meio de um "emendão", é parte de uma estratégia crítica do cronista, que se coloca contra um pretenso caráter saneador do Estado - a contrapelo, sabe que toda intervenção do Estado apenas aumenta a distância entre ele e a sociedade, em vez de diminui-la. O poder político, assim, é pensado por João Antônio como parte integrante, certamente o maior, de toda uma série de problemas nacionais, que vão da miséria ao crescimento desordenado das cidades, da ausência de solidariedade social à criminalidade onipresente. São novos tempos, nos quais ocorre um misto de permanência dos problemas e perda progressiva das antigas vantagens que distinguia enquanto particularidades positivas nacionais; um tempo, em suma, que não é mais seu. Nesses tempos sombrios, contudo, ainda mantém um tênue fio de esperança que expressa, na produção da última década de sua trajetória, na farta utilização de uma citação de crônica de Machado de Assis: “O país real, esse é bom, revela os melhores instintos; mas o

\footnotetext{
${ }^{31}$ ANTÔNIO, João. "Em janeiro sonhamos”. Jornal do Brasil, Rio de Janeiro, 16/11/1994b. Caderno B, p. 1.
} 
país oficial, esse é caricato e burlesco" ${ }^{32} \mathrm{O}$ povo, assim, e não os governos, o poder ou as elites nacionais, permanece como o guardião de certa possibilidade de regeneração brasileira, a despeito da situação de precariedade presente.

Para João Antônio, a despeito de todos os males que o Brasil passava na década de 1990, o que movia seu programa literário - uma relação com o projeto nacional que teima em não abandonar -, ainda sustenta a crença em uma possibilidade de reconstrução, dadas as particularidades que valoriza no país - todas elas de caráter popular, ligadas ao andar de baixo. Assim, se em sua obra tardia podem ser flagrados a lamentação e certa postura agônica em relação ao presente, a nostalgia de um espaço e de uma utopia perdidos no processo da modernização conservadora brasileira, não é também possível esquecer seu interesse empático pelas classes populares, o respeito pelas figuras culturais de tope do país, a crença na possibilidade de construção de uma nova sociedade, a partir de suas peculiaridades de base. João Antônio é, assim, um dos últimos representantes intelectuais cuja obra é devotada a pensar o país na perspectiva de uma formação nacional, que parece abortada nos últimos anos do século XX, fato pelo qual muito provavelmente lhe foi cobrado certo degredo do meio cultural do momento. João Antônio já não pertencia àquele tempo, mas morrera acreditando que "somos capazes de uma alegria ainda única no planeta Terra", e que "o Sol não demora a voltar". ${ }^{33}$

Recebido em: 03/06/2016. Aprovado em: 19/07/2016.

\footnotetext{
${ }^{32}$ Ibidem, p. 12.

${ }^{33}$ ANTÔNIO, João. "Falta o Ministério da Vergonha”. Semanário, São Paulo, 14/01/1991, p. 50.
} 